\title{
Ekonomske imigracije v Republiko Slovenijo
}

UDK: 331.556.44(497.4)(045)

\section{Radivoj Radak}

Ministrstvo za delo, družino in socialne zadeve RS

radivoj.radak@gov.si

\section{IZVLEČEK}

Republika Slovenija se je $z$ osamosvojitvijo znašla v novem položaju v sistemu meddržavnih selitev in urejanja tokov delovnih migracij. Med prvimi zakoni po osamosvojitvi je bil sprejet Zakon o zaposlovanju tujcev (Ur.I. RS, št. 33/92). Na podlagi resolucije in v skladu z Državnim programom Republike Slovenije za prevzem pravnega reda Evropske unije do konca 2002 je Republika Slovenija sprejela nov sistemski zakon o zaposlovanju in delu tujcev (Ur. I. RS, št. 66/00), ki je kot glavni instrument za regulacijo priliva tuje delovne sile uvedel kvotni sistem (prag je $5 \%$ aktivnega prebivalstva). $V$ osmih letih izvajanja Zakona o zaposlovanju in delu tujcev so se pokazale nejasnosti in pomanjkljivosti zakonske ureditve, ki so omogočale tudi zlorabo zakona, zato so bile v letih 2005 in 2007 sprejete spremembe in dopolnitve ZZDT.

Ključne besede: Republika Slovenija, Evropska unija, migracijski sistem, delovne migracije, zaposlovanje tujcev, prosto gibanje delavcev.

JEL: J61, J48

\section{Uvod}

Migracije so v svetu prisotne že od nekdaj, ko so države odpirale ali zapirale svoje meje za delavce migrante, glede na stanje ekonomije oziroma potreb trga dela. Neurejen položaj delavcev migrantov in njihova odvisnost od delodajalcev oziroma od države gostiteljice sta vodila k diskriminaciji tujih delavcev migrantov glede njihovega vstopa na ozemlje države gostiteljice in dela.

Na ravni Evropske unije načelo prostega gibanja delavcev državam članicam preprečuje, da bi neposredno ali posredno razlikovale med delavci EU 


\section{Radivoj Radak}

\section{Ekonomske migracije v Republiko Slovenijo}

in njihovimi družinami na podlagi državljanstva $v$ zadevah, povezanih $z$ zaposlovanjem. Zagotavlja tudi enako obravnavo glede nastanitev ter davčnih in socialnih ugodnosti. Prosto gibanje delavcev je bil tudi eden od prvih ciljev, za uresničitev katerega so si prizadevali utemeljitelji evropskih integracij. Že v Rimski pogodbi iz leta 1957 je bil princip prostega gibanja delavcev eden od štirih temeljev prostega trga: prost pretok blaga, storitev, kapitala in oseb.

Prosto gibanje delavcev pa ni bilo uveljavljeno čez noč. Vlade držav članice EU so se bale takojšnjega odpiranja nacionalnih trgov dela za delavce migrante, tudi zaradi ohranjanja socialnega miru. Korak za korakom so načelo prostega gibanja delavcev dokončno uresničili leta 1968 s sprejetjem Uredbe Sveta 1612/68/EGS o svobodnem gibanju delavcev znotraj skupnosti.

Strah pred takojšnjim odpiranjem nacionalnih trgov dela držav članic je bil prisoten pri vseh nadaljnjih širitvah EU, še posebej pri vstopu novih manj razvitih držav (Grčija, Španija in Portugalska). Takrat so države članice uveljavile 5letno prehodno obdobje, ki pa ni veljalo pri vključevanju bogatih držav (Anglija, Irska, Danska, Švedska in Avstrija). V času izvajanja prehodnega obdobja so države članice lahko ohranile omejitve glede prostega pretoka državljanov novih držav članic, niso pa smele omejitev zaostrovati.

Princip prostega gibanja delavcev je bil dejansko uveljavljen s sekundarno zakonodajo in sicer z Uredbo 1612/68/EGS o svobodnem gibanju delavcev znotraj Skupnosti in Uredbo1408/71/EGS o uporabi sistemov socialne varnosti za zaposlene osebe, samozaposlene osebe in njihove družinske člane, ki se gibljejo v Skupnosti. Direktiva 68/360/EGS pa je uzakonila pravico zapustiti ozemlje svoje države, pravico vstopiti v drugo državo članico in pravico bivanja $\checkmark$ drugi državi članici na podlagi »dovoljenja za prebivanje za državljana države članice». Določbe navedenih predpisov morajo spoštovati vse države članice. Noben akt državnega parlamenta jih ne more preklicati. Pri tem je treba poudariti, da se zakonodaja EU na področju prostega gibanja oseb nenehno spreminja in nadgrajuje. Sedaj veljavna Direktiva 2004/38/ES Evropskega parlamenta in Sveta z dne 29. aprila 2004 o pravici državljanov Unije in njihovih družinskih članov do prostega gibanja in prebivanja na ozemlju držav članic, je spremenila Uredbo (EGS) št. 1612/68 in razveljavila Direktive: 64/221/ EGS, 68/360/EGS， 72/194/EGS，73/148/EGS,75/34/EGS， 75/35/EGS， 90/364/EGS, 90/365/EGS in 93/96/EEC. Direktiva velja tudi za države članice Evropskega gospodarskega prostora.

Namen članka je predstaviti ekonomske imigracije $\vee$ Slovenijo po osamosvojitvi in predstaviti spremembe po polnopravnem članstvu Republike 
Slovenije $\vee$ Evropski uniji. $\vee$ drugem poglavju so predstavljene razmere po osamosvojitvi in razvoj zakonodaje do vstopa Republike Slovenije v Evropsko unijo. $\vee$ tretjem poglavju je predstavljena zakonodaja EU na področju prostega pretoka oseb in ureditev $\vee$ Pristopni pogodbi, predvsem prehodno obdobje in pravice slovenskih državljanov do dostopa na trg dela starih in novih držav članic in obratno. $V$ četrtem poglavju so opisane spremembe Zakona o zaposlovanju in delu tujcev (ZZDT) na katere je vplivala zakonodaja EU in razmere na trgu dela, predvsem visoka gospodarska rast $v$ letih od 2006 do leta 2008. V zaključku so nakazani nadaljnji potrebni ukrepi Slovenije na področju ekonomskih imigracij.

\section{Pregled ekonomskih imigracij v samostojni Sloveniji}

\subsection{Od osamosvojitve do leta 2000}

Republika Slovenija se je z osamosvojitvijo znašla v novem položaju v sistemu meddržavnih selitev. Priseljevanje $\vee$ Republiko Slovenijo pred razpadom SFR Jugoslavije je $\vee$ glavnem potekalo $\vee$ kontekstu notranjih jugoslovanskih selitev glede na obstoječe gospodarske potrebe. $V$ obdobju tranzicije so se spremenile potrebe na trgu dela in struktura domačih iskalcev zaposlitve. Povečalo se je tudi povpraševanje po tujih storitvah, pogojenih z možnostjo gibanja napotenih delavcev.

Pogoje pod katerimi se je lahko tuj državljan oziroma oseba brez državljanstva zaposlila, oziroma delala $\vee$ Republiki Sloveniji, je urejal Zakon o zaposlovanju tujcev $(Z Z T)^{\mathbf{1}}$, ki je bil sprejet med prvimi po osamosvojitvi.

$\checkmark$ okviru tedanjih zakonskih rešitev so bile podrobneje urejene le tiste oblike dela, ki so vezane na delovna razmerja (zaposlitve pri delodajalcih in pogodbeno delo, kot jih je določal Zakon o delovnih razmerjih) ob upoštevanju stanja in razmer na trgu dela. Druge oblike dela, ki izhajajo iz pravice oseb, da z osebnim delom opravljajo dejavnost (obrtne in obrti podobne dejavnosti) pa je ZZT prepuščal urejanju v drugih zakonih (10. člen ZZT) in ga je dovoljeval, kadar je tujec pridobil dovoljenje drugega pristojnega organa. Tudi dela drugih tujih fizičnih in pravnih oseb, ki so pod različnimi pogoji pridobivali dohodke iz dela v

1 Ur.I. RS, št. 33/92. 


\section{Radivoj Radak}

\section{Ekonomske migracije v Republiko Slovenijo}

Republiki Sloveniji, ZZT podrobneje ni urejal. Najpogosteje so bili to interesi za izvajanje storitev tujih podjetij z napotenimi delavci. Za izvajanje storitev z napotenimi delavci je tuje podjetje moralo za svoje napotene delavce pridobiti poslovni vizum (11. člen ZZT). Te primere je določal 8. člen Zakona o tujcih, ki pa ni določal, kdaj so izpolnjeni pogoji za pridobitev poslovnega vizuma. Zakon o tujcih se je skliceval na predpise, ki so urejali tuja vlaganja in opravljanje zunanjetrgovinskega poslovanja ali opravljanje strokovnega dela, določenega s pogodbo o poslovno-tehničnem sodelovanju oz. dolgoročni proizvodnji kooperaciji oziroma prenosu tehnologije. Področje ekonomskih migracij je poleg ZZT urejalo več zakonov in sicer:

- Zakon o tujcih (Ur.I. RS, 61/99),

- Zakon o tujih vlaganjih (Ur. I. SFRJ, št. 77/88, Ur. I. RS, št. 20/95,23/99-ZDP-1),

- Zakon o gospodarskih družbah (Ur. I. RS, št. 30/93, 29/94, 82/94, 20/98, 32/98, 37/98, 84/98, 6/99),

- Zakon o zunanjetrgovinskem poslovanju (Ur. I. RS, št. 13/93, 66/93, 7/94, $58 / 95)$ in

- Marakeški sporazum o ustanovitvi svetovne trgovinske organizacije, Aneks 1B: Splošni sporazum o trgovini s storitvami - Lista specifičnih obvez RS (Ur. I. RS, št. 36/95).

ZZT je bil restriktiven in selektiven, saj so tujci lahko delali na območju Republike Slovenije le na podlagi pridobljenega delovnega dovoljenja oziroma drugih dovoljenj, ki so nadomeščala delovno dovoljenje in jih je ZZT taksativno našteval. Pri tem velja izpostaviti, da je tujcu s statusom dnevnega migranta ZZT omogočal, da za razliko od drugih tujcev pridobi osebno delovno dovoljenje. S tem mu je bila dana možnost zaposlitve pri kateremkoli delodajalcu na območju RS, delo ni bilo vezano na obmejno območje, dovoljenje pa je bilo časovno omejeno na eno leto.

Delovna dovoljenja so bila glede njihove veljavnosti omejena na čas do enega leta. $\vee$ zakonu ni bilo materialne podlage za podaljševanje veljavnosti delovnih dovoljenj. Tujec je lahko pridobil tudi osebno delovno dovoljenje za nedoločen čas in sicer po prehodnih določbah takoj, če je imel najmanj 10 let delovne dobe, ali pa po 10 letnem prebivanju na podlagi dovoljenja za stalno prebivanje (8. in 23. člen ZZT). Poleg dela tujcev pod pogoji, ki jih je določal ZZT, je bilo v Republiki Sloveniji dopustno tudi delo oseb, ki jim je država dajala začasno zatočišče in sicer pod pogoji in na način, ki jih je določal poseben zakon in sicer Zakon o začasnem zatočišču iz leta 1997. 
Iz vsebine tedaj veljavnega zakona in zakonodaje na katero se je zakon navezoval je mogoče povzeti načelni zakonodajni pristop primarnega zakonskega urejanja nujnih področij, ki so zahtevala novo zakonsko ureditev zaradi novonastalih razmer z uveljavitvijo državnosti Republike Slovenije.

Z razvojem sodobne postindustrijske družbe in s tem povezane selitve aktivnosti v storitvene dejavnosti so se spreminjale tudi oblike dela in dejavnosti prebivalstva, kakor tudi drugi migracijski tokovi. Uvajale so se neformalne oblike dela in zaslužka, pogosto tudi na meji legalnosti, kar je bil splošen pojav, tako $\vee$ razvitih državah Evrope kot $v$ državah t.i. tranzicije, in je bil posledica brezposelnosti ter ekonomske negotovosti. Obenem je naraščal tudi delež samozaposlenega prebivalstva. Vse to je bilo še bolj izraženo pri tujcih - ekonomskih migrantih, ki so bili po eni strani pripravljeni sprejeti delo za minimalno plačilo in brez vsake delovnopravne in socialne zaščite (socialni dumping), po drugi strani pa so se tujci, zaradi liberalnih pogojev za opravljanje pridobitnih in drugih dejavnosti, zlahka uveljavljali kot menedžerji v novoustanovljenih podjetjih in kot ponudniki tujih storitev.

Statistični podatki $v$ tem obdobju kažejo skoraj enako število osebnih delovnih dovoljenj za nedoločen čas, porast števila delovnih dovoljenj na vlogo delodajalca ter predvsem $\vee$ zadnjih dveh letih porast števila osebnih delovnih dovoljenj za določen čas.

Tabela 1: število veljavnih delovnih dovoljenj v letih od 1992 do 2000

\begin{tabular}{|l|c|c|c|c|}
\hline $\begin{array}{l}\text { Datum: } \\
31 / 12\end{array}$ & $\begin{array}{c}\text { Delovna } \\
\text { dovoljenja }\end{array}$ & $\begin{array}{c}\text { Osebna delov- } \\
\text { na dovoljenja } \\
\text { za nedoločen } \\
\text { čas }\end{array}$ & $\begin{array}{c}\text { Osebna delov- } \\
\text { na dovoljenja } \\
\text { za določen čas }\end{array}$ & Skupaj \\
\hline 1992 & 4.429 & 13.352 & 18.853 & 36.643 \\
\hline 1993 & 17.011 & 13.663 & 871 & 31.545 \\
\hline 1994 & 20.906 & 13.660 & 801 & 35.367 \\
\hline 1995 & 23.504 & 13.727 & 716 & 37.947 \\
\hline 1996 & 23.804 & 13.738 & 653 & 38.194 \\
\hline 1997 & 20.883 & 13.744 & 661 & 35.287 \\
\hline 1998 & 20.373 & 13.693 & 702 & 34.768 \\
\hline 1999 & 22.965 & 13.680 & 1.146 & 37.791 \\
\hline 2000 & 24.429 & 13.668 & 2.223 & 40.320 \\
\hline
\end{tabular}

Vir: ZRSZ 


\section{Radivoj Radak}

\section{Ekonomske migracije v Republiko Slovenijo}

\subsection{Od leta 2000 do polnopravnega članstva Slovenije v Evropski uniji}

Z Resolucijo o imigracijski politiki Republike Slovenije ${ }^{2}$, ki jo je Državni zbor Republike Slovenije sprejel 14. maja 1999, so bili prvič določeni temelji imigracijske politike Republike Slovenije, kakor tudi najnujnejši splošni ukrepi za doseganje uresničevanja stališč resolucije na področju pravnih sredstev.

Resolucija je določila, da je treba zakon, s katerim se urejajo pogoji za delo tujih državljanov ali oseb brez državljanstva $\vee$ Republiki Sloveniji, spremeniti tako, da ga bo kot temeljni materialni in procesni predpis mogoče uporabiti za zaščito domačega trga dela in uravnavanja novega pritoka delovne sile. Zakonske spremembe $v$ posameznih področnih zakonih naj bi omogočile izvajanje stališč sprejete resolucije.

$\mathrm{Na}$ tej podlagi in $v$ skladu z Državnim programom Republike Slovenije za prevzem pravnega reda Evropske unije do konca leta 2002 je bil 14. julija 2000 $\checkmark$ Državnem zboru sprejet nov sistemski zakon o zaposlovanju in delu tujcev $(Z Z D T)^{3}$, s čimer je bil realiziran tudi sprejeti resolucijski ukrep na zakonodajnem področju urejanja zaposlovanja in dela tujcev.

Z novim sistemskim zakonom so bili uzakonjeni predvsem naslednji resolucijski cilji na zakonodajnem področju:

- sistemska povezanost zakona o zaposlovanju in delu tujcev z zakonom o tujcih,

- regulacija dostopa do trga dela $v$ odvisnosti od vrste oziroma namena dela in trajanja dejavnosti (z različnimi vrstami delovnih dovoljenj: osebno delovno dovoljenje, dovoljenje za zaposlitev, dovoljenje za delo, prijava dela),

- selektivnost pri omejevanju dostopa do zaposlitve in dela odvisno od narave dela ter razmer na trgu dela,

- prioritetna obravnava že priseljenih tujcev pred novimi iskalci zaposlitve in dela,

- združevanje pravice do zaposlitve in dela s pravico do bivanja (rezidenti, tujci, ki že dalj časa bivajo v državi, begunci, potomci slovenskih državljanov, družinski člani),

2 Ur.I. RS, št. 40/99

3 Ur. I. RS, št. 66/00 
- možnost uravnavanja ekonomske imigracije z zakonsko določenimi omejitvenimi instrumenti (kvote, prepovedi in omejitve, ki jih lahko sprejme Vlada Republike Slovenije pod pogoji in na način določen z ZZDT).

ZZDT je kot glavni instrument za regulacijo priliva tuje delovne sile uvedel kvotni sistem (prag je 5\% aktivnega prebivalstva). Omejitev s kvoto je namenjena kategorijam tujcev, ki na novo oziroma letno prihajajo $v$ državo $z$ namenom zaposlitve ali izvajanja drugih občasnih oblik dela na različnih pogodbenih osnovah. Poleg kvote ima zakon tudi druge instrumente za uravnavanje razmer na trgu dela, ki so v pristojnosti Vlade Republike Slovenije. Vlada jih lahko sprejme, kadar bi prevelik priliv tuje delovne sile $\vee$ okviru različnih oblik lahko vplival na poslabšanje stanja zaposlenosti na domačem trgu dela.

ZZDT je $v$ skladu s pravom Evropske unije definiral vrste in pogoje za čezmejno delo in izvajanje storitev z napotenimi delavci, ki sicer formalno med opravljanjem dela $\vee$ Republiki Sloveniji še naprej ostajajo $v$ delovnem razmerju v tujini. Na novo so bili uzakonjeni tudi posebni, manj zahtevni postopki in pogoji za opravljanje storitev tujih izvajalcev, omejenih na kratko časovno obdobje.

ZZDT je določil, da so državljani držav članic EU, do uveljavitve acquisa oziroma do sprostitve trgov dela za slovenske državljane obravnavani enako kot tujci iz tretjih držav, če prihajajo $v$ državo z namenom zaposlitve ali dela.

Statistični podatki $v$ tem obdobju kažejo konstanten porast osebnih delovnih dovoljenj, padec števila dovoljenj za zaposlitev ter porast števila dovoljenj za delo. $V$ skupnem številu se je število delovnih dovoljenj od konca leta 2001 do konca leta 2003 povečalo za 5.595 delovnih dovoljenj.

Tabela 2: število veljavnih delovnih dovoljenj v letih od 2001 do 2003

\begin{tabular}{|l|c|c|c|c|}
\hline $\begin{array}{c}\text { Datum: } \\
31 / 12\end{array}$ & $\begin{array}{c}\text { Osebna delovna } \\
\text { dovoljenja }\end{array}$ & $\begin{array}{c}\text { Dovoljenja za } \\
\text { zaposlitev }\end{array}$ & $\begin{array}{c}\text { Dovoljenja za } \\
\text { delo }\end{array}$ & Skupaj \\
\hline 2001 & 15.090 & 16.434 & 2408 & 33.932 \\
\hline 2002 & 17.995 & 13.580 & 4484 & 36.059 \\
\hline 2003 & 20.794 & 12.381 & 6352 & 39.527 \\
\hline
\end{tabular}

Vir: ZRSZ 


\section{Radivoj Radak}

\section{Ekonomske migracije v Republiko Slovenijo}

Porast števila osebnih delovnih dovoljenj in dovoljenj za delo je posledica novih določb ZZDT. Pri osebnih delovnih dovoljenjih je ZZDT uvedel osebna delovna dovoljenja z veljavnostjo treh let, za katera so lahko zaprosili ožji družinski člani slovenskega državljana, ožji družinski člani tujca z osebnim delovnim dovoljenjem za nedoločen čas, slovenski izseljenci do tretjega kolena $\checkmark$ ravni črti, tujci, ki so bili pet let neprekinjeno zaposleni pri istem delodajalcu in samozaposleni tujci, ki so bili tri leta neprekinjeno samozaposleni. Pri dovoljenjih za delo pa je ZZDT prinesel 5 novih vrst dovoljenj za delo in sicer za: delo z napotenimi tujci, za usposabljanje in izpopolnjevanje, za sezonsko delo tujcev, za delo tujih poslovodnih delavcev in za individualne storitve tujcev.

\section{Polnopravno članstvo Slovenije v Evropski uniji}

\subsection{Mobilnost znotraj EU}

Statistični podatki za Evropsko unijo pred širitvijo 1. maja 2004 so kazali, da pravila prostega gibanja delavcev znotraj držav članic EU-15 bistveno ne povečujejo mobilnosti delavcev med državami članicami. Od takratnega skupnega števila 370 mio. prebivalcev $v$ EU, jih je le 5 mio. (1,35\%) živelo $v$ drugi državi članici, dodatnih 2 mio. oseb $(0,5 \%)$ pa jih je živelo v svoji državi in delalo $\checkmark$ drugi državi članici (čezmejni delavci). $\vee$ zadnjih letih pa je prišlo do postopnega povečanja mobilnosti. Število mobilnih delavcev $\vee$ EU-15 se je povečalo od okrog 470000 oseb leta 2000 na okrog 610000 leta 2005 (Raziskava o evropski delovni sili) ${ }^{4}$.

Razlogi za nizko mobilnost so različni: selitev $v$ drugo okolje, premajhno poznavanje socialnih in drugih pravic, ki jim gredo $v$ drugi državi, vsakodnevno ali tedensko potovanje, jezikovne ovire in podobno. Delavce, še posebej nižje plačane, tudi višja plača $\vee$ drugi državi članici ne prepriča $v$ selitev oziroma potovanje na delo $v$ drugo državo.

Glede na opravljene raziskave in trende Slovenija ob polnopravnem članstvu v EU na področju prostega gibanja delavcev ni pričakovala bistvenih

4 Vpliv priključitve novih držav članic je prav tako obravnavan $v$ „Poročilu o delovanju prehodnih ureditev, določenih v pristopni pogodbi iz leta 2003 (obdobje od 1. maja 2004 do 30. aprila 2006)“ Komisije, COM(2006) 48, 8.2.2006. 
sprememb, oziroma bistvenega povečanja migracijskih gibanj. Večja migracijska gibanja smo pričakovali le na obmejnih področjih s sosednjimi državami (Italija, Avstrija, Madžarska), po uveljavitvi prostega gibanja delavcev.

\subsection{Pogodba o pristopu in ureditev prehodnega obdobja za gibanje delavcev}

S podpisom Pogodbe o pristopu 10 novih držav članic k Evropski uniji v Atenah 16.4.2003 so se zaključila pogajanja s 15 "starimi« državami članicami o pogojih pristopa. Prost pretok oseb vključuje prosto gibanje delavcev, priznavanje poklicnih kvalifikacij, koordinacijo sistemov socialnih varnosti in državljanske pravice. Prehodno obdobje je veljalo, oziroma velja le za prosto gibanje delavcev, medtem ko se je za priznavanje poklicnih kvalifikacij, koordinacijo sistemov socialnih varnosti in državljanske pravice od prvega dne pristopa Republike Slovenije $\vee$ EU uporabljal evropski pravni red. V skladu s Pogodbo o pristopu od 16. aprila 2003 ni smela nobena stara država članica uvajati novih omejevalnih ukrepov $v$ svojo nacionalno zakonodajo zoper državljane novih držav članic niti niso smele nove države članice nasproti državljanom sedanjih držav članic.

\subsection{1 "Stare« države članice}

Prvi dve leti po pristopu, od 1. maja 2004, stare države članice niso uporabljale prvih 6 členov Uredbe 1612/68, ki določajo prosto gibanje delavcev med državami članicami, temveč nacionalno zakonodajo ali ukrepe iz dvostranskih sporazumov, ki urejajo dostop slovenskih državljanov na njihove trge dela z možnostjo, da uvedejo večjo svobodo prostega gibanja na dan pristopa, vključno s popolnim dostopom na trg dela. Pred iztekom prvih 2 let oziroma pred začetkom naslednjega triletnega obdobja je morala vsaka stara država članica, glede na stanje na svojem trgu dela, Komisiji sporočiti, ali bo še naprej uporabljala nacionalno zakonodajo. $V$ nasprotnem primeru bi veljalo prosto gibanje delavcev. Zadnji dve leti prehodnega obdobja lahko sedanje države članice uporabljajo svojo nacionalno zakonodajo le $v$ primeru resnih motenj, ali grožnje le-teh na trgu dela.

Republika Slovenija je $\vee$ pogajalskih izhodiščih uveljavila načelo vzajemnosti. To pomeni, da bi lahko tudi Slovenija $\vee$ času 7-letnega prehodnega obdobja nasproti vsake stare države članice, ki uveljavlja nacionalne ukrepe $v$ zvezi z gibanjem delavcev, uveljavljala enakovredne ukrepe. Zakon o 
Radivoj Radak

Ekonomske migracije v Republiko Slovenijo

zaposlovanju in delu tujcev iz leta 2000 je $v$ tretjem odstavku 3. člena določal, da se določbe tega zakona ne uporabljajo za državljane držav članic EU, če so z mednarodnim sporazumom vzajemno omogočeni prost dostop do trga dela in zaposlovanja in prost pretok storitev, ki se izvajajo z napotenimi delavci, ter druge oblike dela po tem zakonu. $V$ kolikor posamezna država članica EU ne bi liberalizirala dostopa na svoj trg dela za slovenske državljane in bi za njihovo zaposlovanje uporabljala svojo nacionalno zakonodajo, bi se tudi njeni državljani $\checkmark$ Sloveniji obravnavali po določbah Zakona o zaposlovanju in delu tujcev. Vlada Republike Slovenije je po zaključku dveletnega prehodnega obdobja, na podlagi lastnih in skupnih pobud z novimi državami članicami EU za odpravo prehodnega obdobja in glede na podatke o nizkem številu državljanov starih držav članic EU na slovenskem trgu dela, dne 25. maja 2006 sprejela sklep o ukinitvi vzajemnosti do starih držav članic EU in tako od tega dne odprla svoj trg dela za vse državljane EU.

Po zaključku druge (tri letne) faze prehodnega obdobja, ki je trajala do 30. aprila 2009, le še dve državi članici EU (Republika Avstrija in Zvezna Republika Nemčija) uveljavljata prehodno obdobje. Zadnja faza prehodnega obdobja lahko traja še največ dve leti, oziroma do 30. aprila 2011.

\subsubsection{Slovenski državljani na delu v starih državah članicah}

Četudi bi katerakoli stara država članica uveljavljala prehodno obdobje, Pogodba o pristopu določa, da imajo slovenski državljani dostop na trg dela stare države članice, če so na dan pristopa (1. maja 2004) zakonito delali v tej državi članici in imeli dovoljenje za neprekinjeno obdobje 12 mesecev ali več. Isto bi veljalo tudi za slovenske državljane, ki bi pridobili delovno dovoljenje $\vee$ stari državi članici za čas 12 mesecev ali več po 1. maju 2004. Če jim je izdano dovoljenje za čas krajši od 12 mesecev, ne uživajo pravice dostopa na trg dela te države članice. Pravico dostopa na trg dela stare države članice bi slovenski državljani izgubili, če bi prostovoljno zapustili trg dela stare države članice.

\subsubsection{Družinski člani}

Zakonec in nepreskrbljeni otroci do starosti 21 let, ki so na dan pristopa zakonito prebivali z delavcem na ozemlju stare države članice, so imeli po pristopu neposreden dostop na trg dela te države članice, če je delavcu dovoljen dostop na trg dela te države članice za čas 12 mesecev ali več. Zakonec in nepreskrbljeni otroci do starosti 21 let, ki so pridobili dovoljenje za zakonito 


\section{Ekonomske migracije v Republiko Slovenijo}

prebivanje z delavcem na ozemlju stare države članice po dnevu pristopa, so imeli dostop na trg dela te države članice po 18 mesecih zakonitega prebivanja $\checkmark$ tej državi, ali od tretjega leta od dneva pristopa, glede na to kar je za družinskega člana ugodneje.

\subsubsection{Nove države članice}

Med novimi državami članicami je ob vstopu v EU (1. maj 2004) veljalo prosto gibanje delavcev, z možnostjo, da so lahko takoj po polnopravnem članstvu v EU uvedle varnostno klavzulo nasproti katerikoli novi državi članici. Varnostno klavzulo lahko nova država članica uvede nasproti katerikoli novi državi članici v času 7-letnega prehodnega obdobja, če katerakoli stara država članica uporablja nacionalno zakonodajo oziroma nacionalne ukrepe nasproti katerekoli nove države članice.

\subsubsection{Varnostna klavzula}

Stare države članice lahko uporabijo t.i. varnostno klavzulo, če bi po 2letnem prehodnem obdobju uvedle prosto gibanje delavcev (uporabljale pravila EU glede prostega gibanja delavcev) in bi v času do konca 7-letnega prehodnega obdobja ugotovile, da imajo ali pričakujejo resne motnje na svojem trgu dela, ki bi lahko resno ogrozile življenjsko raven ali raven zaposlenosti $v$ določeni regiji ali poklicu. Varnostno klavzulo lahko uvedejo zoper katerokoli novo državo članico in odložijo uporabo pravil EU glede prostega gibanja delavcev, da se vzpostavi stabilno stanje na trgu dela $v$ tej regiji oziroma poklicu. Varnostna klavzula do sedaj še nikoli ni bila uvedena.

\subsubsection{EURES}

Slovenija je $\vee$ Evropske službe za zaposlovanje (EURES) ${ }^{\mathbf{5}}$ vstopila s polnopravnim članstvom v EU, 1. maja 2004. V Evropske službe za zaposlovanje je vključen Zavod Republike Slovenije za zaposlovanje (ZRSZ). EURES je bil zaradi zagotavljanja prostega gibanja delavcev ustanovljen leta 1993 s posebno Odločbo evropske Komisije. Predstavlja skupno omrežje Komisije, javnih služb za zaposlovanje in njihovih nacionalnih partnerjev iz držav, ki obsegajo skupni Evropski gospodarski prostor. Njegova temeljna naloga je posredovanje in izmenjava

5 European Employment Services Network. 


\section{Radivoj Radak}

\section{Ekonomske migracije v Republiko Slovenijo}

informacij o prostih delovnih mestih, prosilcih za zaposlitev ter o življenjskih in delovnih razmerah $v$ posameznih državah članicah.

\subsubsection{Priznavanje kvalifikacij}

Za vzpostavitev sistema priznavanja reguliranih poklicev prehodno obdobje ni veljalo, zato je Slovenija pričela izvajati postopke priznavanja kvalifikacij za opravljanje reguliranih poklicev oziroma reguliranih poklicnih dejavnosti z dnem polnopravnega članstva $v$ Evropski uniji.

\subsubsection{Koordinacija sistemov socialne varnosti}

Pravila koordinacije sistemov socialne varnosti določata Uredba Sveta (EGS) 1408/71 z dne 14. junija 1971 o uporabi sistemov socialne varnosti za zaposlene osebe, samozaposlene osebe in njihove družinske člane, ki se gibljejo znotraj Skupnosti ter Uredba Sveta 574/72 (EGS) z dne 21. marca 1972 o določitvi postopka za izvajanje Uredbe (EGS) št. 1408/71 o uporabi sistemov socialne varnosti za zaposlene osebe, samozaposlene osebe in njihove družinske člane, ki se gibljejo znotraj Skupnosti. Oba predpisa sta direktno uporabna $\checkmark$ pravnem redu držav članic Evropske unije, kar pomeni, da Sloveniji ni bilo treba sprejemati zakonodaje za prenos njunih določb $v$ pravni red, ampak so te določbe za Slovenijo začele veljati z dnem polnopravnega članstva $\vee$ Evropski uniji.

Uredba sveta št. 1408/71 omogoča gibanje delavcev in njihovih družinskih članov znotraj skupnosti s pravili koordinacije sistemov socialne varnosti. Z Uredbo so med drugim zajeta naslednja področja socialne varnosti:

- dajatve za bolezen in materinstvo;

- dajatve za invalidnost, vključno s tistimi za vzdrževanje ali izboljšavo zmožnosti ustvarjanja dohodka;

- dajatve za starost;

- dajatve preživelim družinskim članom;

- dajatve za nesreče pri delu ali poklicne bolezni;

- posmrtnine;

- dajatve za brezposelnost in

- družinske dajatve. 
29. aprila 2004, torej dva dni pred uradnim pričetkom članstva novih držav članic $\vee$ EU, je bila sprejeta nova osnovna uredba, to je Uredba 883/2004, ki bo nadomestila Uredbo št. 1408/71. Določeno je bilo, da se bo uredba začela uporabljati, ko bo pričela veljati tudi nova izvedbena uredba, ki bo nadomestila dosedanjo izvedbeno uredbo 574/72, in bo sprejeta vsebina aneksov k osnovni uredbi, kar bo predvidoma 1. 3. 2010.

\section{Spremembe Zakona o zaposlovanju in delu tujcev po letu 2004}

V osmih letih izvajanja Zakona o zaposlovanju in delu tujcev so se pokazale nejasnosti in pomanjkljivosti zakonske ureditve, ki so omogočale tudi zlorabo zakona, zato so bile $v$ letih 2005 in 2007 sprejete spremembe in dopolnitve ZZDT.

\subsection{Spremembe in dopolnitve Zakona o zaposlovanju in delu tujcev iz leta $2005^{6}$}

Cilj sprememb je bil:

- odpraviti pomanjkljivosti, ki so bile ugotovljene vse od uveljavitve zakona leta 2001,

- jasneje definirati posamezne kriterije ali omejitve za pridobitev delovnega dovoljenja in

- preprečiti zlorabe, ki jih je ZZDT zaradi nejasnosti ali nedorečenosti omogočal.

Po nekaj mesecih izmenjave mnenj in iskanja najboljših rešitev z izvajalci in uporabniki so bile pripravljene spremembe in dopolnitve ZZDT. Glavne vsebinske spremembe in dopolnitve so bile:

- za pridobitev delovnega dovoljenja za samozaposlene tujce je ZZDT zaostril pogoje in določil enoletno predhodno prebivanje $\vee$ Sloveniji. Tujci so namreč izkoriščali možnost lahke in finančno ugodne pridobitve delovnega

6 Ur. I. RS, št. 101/05, z dne 11.11.2005 


\section{Radivoj Radak}

\section{Ekonomske migracije v Republiko Slovenijo}

dovoljenja zgolj na podlagi vpisa $v$ vpisnik samostojnih podjetnikov posameznikov in so na tej podlagi vstopali na slovenski trg dela.

- uvedena je bila možnost dodatnega izobraževanja tako tujih kot slovenskih delavcev $\vee$ slovenskih gospodarskih družbah $\vee$ primerih, ko je slovenska družba kapitalsko ali poslovno povezana s tujo družbo. Na ta način je bila realizirana pobuda gospodarstva za širitev in večji vpliv slovenskega gospodarstva $\vee$ tretjih državah, predvsem $\vee$ državah bivše Jugoslavije in Sovjetske zveze,

- $\quad$ pri čezmejnem opravljanju storitev z napotenimi ali nameščenimi delavci oziroma pri gibanju oseb znotraj združb je ZZDT zaostril pogoje in zahteval predhodno enoletno zaposlitev tujca pri delodajalcu, ki ga napotuje na delo v Slovenijo, kar je v skladu s politiko EU pri pogajanjih v okviru Svetove trgovinske organizacije za izvajanje storitev podjetij iz tretjih držav,

- $\quad$ pri sezonskem delu tujcev je ZZDT dal možnost zaposlitve takoj po izteku sezonskega dela, kar je omogočilo delodajalcem, da zaposlijo tujca, ki ga že dobro poznajo,

- omejeno je bilo število zastopnikov na enega zastopnika v gospodarskih družbah in pri samostojnih podjetnikih, ki zaposlujejo deset ali manj delavcev, določen je bil čas veljavnosti delovnega dovoljenja na 2 leti in določeni so bili pogoji za ponovno izdajo delovnega dovoljenja.

Že dve leti kasneje so bile sprejete nove spremembe in dopolnitve ZZDT.

\subsection{Spremembe in dopolnitve Zakona o zaposlovanju in delu tujcev iz leta $2007^{7}$}

Glavne vsebinske spremembe in dopolnitve so bile:

- Uskladitev z zakonodajo, kjer so bile glavne spremembe prenos novih pojmov v skladu s sprejetimi določbami uredb in direktiv na ravni Evropske unije ter natančnejša določitev pristojnosti Vlade RS pri uveljavitvi možnih ukrepov ob motnjah na trgu dela. Dodano je bilo novo poglavje $X V$. A, v katerem sta zakonsko urejena zaposlovanje in izvajanje storitev državljanov EU in njihovih družinskih članov.

7 Ur. I. RS, št. 52/07, z dne 12.6.2007 
- Odprave pomanjkljivosti, oziroma izboljšave starega ZZDT, na katere so opozarjali uporabniki zakona, ZRSZ in socialni partnerji:

- osebno delovno dovoljenje (ODD) za tri leta lahko tujec z najmanj poklicno izobrazbo pridobi po najmanj dveletni neprekinjeni zaposlitvi pri istem delodajalcu. S tem se je bistveno zmanjšalo število postopkov na ZRSZ, tujcu pa je omogočena bistveno lažja prezaposlitev, oziroma prehod k drugemu delodajalcu;

- $v$ agencijah, ki posredujejo delavca drugemu uporabniku, se lahko zaposlujejo tudi tujci z ODD z veljavnostjo treh let, ali za nedoločen čas;

- zaostrili so se pogoji za tujce, ki se želijo v Sloveniji samozaposliti kot samostojni podjetniki ali kot ustanovitelji osebne gospodarske družbe. Za vpis $\vee$ Poslovni register morajo, poleg že zahtevanega enoletnega prebivanja, izkazati še lastna finančna sredstva in lastništvo ali najem poslovnih ali prostorov, kjer imajo sedež. S temi pogoji so bili odpravljeni fiktivni naslovi in težave različnih inšpekcijskih organov in DURS-a $v$ primerih, ko tujcev ni bilo na vpisanem naslovu;

- s ciljem privabljanja raziskovalcev in študentov je tujcem omogočen enostavnejši vstop na slovenski trg dela. Oboji imajo možnost pridobiti ODD za tri leta, če si najdejo delodajalca $v$ roku enega leta po zaključku študija ali raziskovalnega dela;

- prepovedi novega zaposlovanja in dela so na novo opredeljene le za težje kršitve ZZDT, zakona o preprečevanju dela in zaposlovanja na črno in zakona o delovnih razmerjih ter razdeljene na tri, dve in enoletno prepoved novega zaposlovanja, glede na težo kršitve.

- Odprava administrativnih ovir. Z natančno določitvijo pogojev, ki jih morata izpolnjevati delodajalec in tujec pri izdaji delovnega dovoljenja za različne vrste zaposlitve ali dela, so se odpravile nekatere nejasnosti $\checkmark$ dotedanji praksi.

- Druge pomembnejše spremembe s ciljem odpravljanja administrativnih ovir so bile:

- namesto pozitivnega poslovanja $v$ preteklem letu in prepovedi novega zaposlovanja za novoustanovljena podjetja mora delodajalec izkazati 6mesečno poslovanje $v$ višini, ki zagotavlja izplačilo minimalnih plač za 


\section{Radivoj Radak}

\section{Ekonomske migracije v Republiko Slovenijo}

najmanj dva delavca in poravnane davke in prispevke iz naslova zaposlitve in dela v času vložitve vloge za izdajo delovnega dovoljenja;

- poudarek je na postopku pridobivanja prvega delovnega dovoljenja, postopek podaljšanja pa je zelo poenostavljen;

- večino dokazil ZRSZ pridobi po uradni dolžnosti.

Zaradi številnih sprememb in dopolnitev ZZDT so bile spremenjene tudi podzakonske določbe. $\vee$ Pravilnik o delovnih dovoljenjih, prijavi in odjavi dela ter nadzoru nad zaposlovanjem in delom tujcev ${ }^{\boldsymbol{8}}$ je bilo združenih osem do tedaj veljavnih podzakonskih aktov, kar je prispevalo k bistveno boljši preglednosti. Pravilnik omogoča tudi hitrejše postopke izdaje dovoljenj za zaposlitev in zaposlitev tujcev $v$ deficitarnih poklicih.

\subsubsection{Prvi ukrepi Vlade v recesiji}

Zaradi svetovne gospodarske krize in števila brezposelnih oseb, ki je naraščalo od septembra 2008, ko je bilo le 59.303 brezposelnih oseb, konec leta 2008 66.239, konec maja 2009 84.519, konec leta 2009 pa že 96.672 brezposelnih oseb, je Vlada 11. junija 2009 sprejela Uredbo o omejitvah in prepovedih zaposlovanja in dela tujcev. Uredba je bila izdana na podlagi sedmega odstavka 5. člena ZZDT, ki določa, da lahko Vlada RS poleg kvote določi tudi omejitve in prepovedi zaposlovanja in dela tujcev po regijah, področjih dejavnosti, podjetjih in poklicih, kakor tudi omeji ali prepove pritok novih tujih delavcev $v$ celoti ali iz določenih regionalnih področij, kadar je to utemeljeno $z$ javnim ali splošnim gospodarskim interesom. Uredba je stopila $\vee$ veljavo 13. junija 2009 in je uvedla naslednje omejitve in prepovedi:

- Prepoved sezonskega zaposlovanja, razen v kmetijstvu in gozdarstvu. Tujci se lahko zaposlujejo tudi $\vee$ drugih dveh gospodarskih panogah (gradbeništvo ter gostinstvo in turizem, $v$ katerih je z ZZDT sicer omogočeno sezonsko zaposlovanje), vendar na podlagi dovoljenja za zaposlitev, ki se izda po kontroli trga dela, oziroma po preverjanju ali so v evidenci brezposelnih oseb ustrezne domače, ali z njimi izenačene osebe.

- Prepoved izdajanja novih dovoljenj za delo za zastopnike mikro in majhnih podjetij in za zastopnike podružnic, tujcem s prebivališčem na območju Republike Kosovo, ki nimajo dovoljenja za prebivanje $v$ Republiki Sloveniji.

8 Ur. I. RS, št. $37 / 08$

9 Ur. I. RS, št. 44/09 


\section{Ekonomske migracije v Republiko Slovenijo}

Razlog za prepoved je bilo veliko število zlorab delovnih dovoljenj in dovoljenj za prebivanje ter opozoril drugih držav članic EU in EGP, da tujci s slovenskim dovoljenjem za prebivanje opravljajo nedovoljene dejavnosti v njihovih državah.

- Prepoved izdaje novih dovoljenj za zaposlitev delodajalcem, ki tujcev, za katere so že pridobili dovoljenja za zaposlitev, $v$ štirih mesecih niso zaposlili - t.i. dovoljenja »na zalogo«.

- Omejitev zaposlovanja iz določenih regionalnih področij. Glede na dolgoletno statistično povprečje zaposlovanja tujcev iz posameznih tretjih držav je določeno, da se preostanek kvote, določene za dovoljenja za nove zaposlitve $\vee$ višini 11.000 dovoljenj za zaposlitev $\vee$ letu 2009, od uveljavitev Uredbe dalje razdeli na 95\% za državljane bivše skupne države, razen Kosova, $5 \%$ pa za državljane vseh drugih tretjih držav z državljani Republike Kosovo vred. Razlog, zakaj so bili v tem ukrepu vlade državljani Kosova obravnavani posebej, je $v$ dejstvu, da je bilo do konca maja 2009, od skupno 6.554 dovoljenj za zaposlitev, državljanom Kosova izdanih 3.491 dovoljenj za zaposlitev, oziroma 53\%.

- Omejitve in prepovedi izdaje dovoljenj za zaposlitev po poklicih. Zaradi sumov zlorabe, oziroma kaznivih dejanj prostitucije in trgovine z ljudmi je prepovedano novo zaposlovanje t.i. barskih plesalk iz držav, ki za vstop v Republiko Slovenijo potrebujejo vizum, razen iz držav, ki imajo z Evropsko unijo sklenjen sporazum o vizumskih olajšavah. Zaradi lažjega nadzora se lahko programi izvajajo le na eni lokaciji, ki jo delodajalec navede na vlogi za izdajo dovoljenja za zaposlitev.

- Izdaja dovoljenj za zaposlitev za visokokvalificirane tujce. $V$ primeru, da bi bila kvota dovoljenj za zaposlitev (11.000 dovoljenj) izkoriščena, je Vlada določila, da se nerazporejeni del kvote $\vee$ višini 1.000 dovoljenj za zaposlitve nameni za zaposlovanje t. i. visokokvalificiranih delavcev. Tujci morajo imeti izobrazbo, primerljivo z najmanj višješolsko oziroma višjo strokovno izobrazbo na šesti ravni, delodajalec pa mora tujcu izplačevati plačo najmanj $v$ višini 2,5 minimalnih plač.

Statistični podatki v tem obdobju kažejo izreden porast števila dovoljenj za zaposlitev, predvsem $\vee$ letih 2007 in 2008 ter konstanten prirast osebnih delovnih dovoljenj. V skupnem številu se je število delovnih dovoljenj od leta 2004 do konca leta 2008 več kot podvojilo, število EU-prijav (zaposlitve in izvajanje storitev z napotenimi delavci) pa se je do leta 2006 rahlo povečevalo, v letih 2007 in 2008 pa se tudi v tem segmentu kaže izrazito povečanje števila 
Radivoj Radak

Ekonomske migracije v Republiko Slovenijo

državljanov EU na slovenskem trgu dela. V prvih mesecih letošnjega leta pa se kaže upad tako števila delovnih dovoljenj, kot EU-prijav.

Tabela 3: Število veljavnih delovnih dovoljenj in EU-prijav v letih od 2004 do 2009

\begin{tabular}{|c|c|c|c|c|c|c|c|}
\hline $\begin{array}{l}\text { Datum: } \\
31 / 12\end{array}$ & $\begin{array}{c}\text { Osebna } \\
\text { delovna } \\
\text { dovoljenja }\end{array}$ & $\begin{array}{c}\text { Dovoljenja } \\
\text { za } \\
\text { zaposlitev }\end{array}$ & $\begin{array}{c}\text { Dovoljenja } \\
\text { za delo }\end{array}$ & $\begin{array}{c}\text { Skupaj } \\
\text { delovna } \\
\text { dovoljenja }\end{array}$ & $\begin{array}{c}\text { EU- } \\
\text { prijave }\end{array}$ & $\begin{array}{c}\text { Brez } \\
\text { delovnih } \\
\text { dovoljenj }\end{array}$ & $\begin{array}{c}\text { Skupaj } \\
\text { VSE }\end{array}$ \\
\hline 2004 & 22.712 & 12.233 & 4.085 & 39.030 & 1.662 & & 40.692 \\
\hline 2005 & 25.782 & 12.360 & 4.825 & 42.967 & 2.482 & 27 & 45.476 \\
\hline 2006 & 29.871 & 14.501 & 6.362 & 50.734 & 2.895 & 32 & 53.661 \\
\hline 2007 & 31.751 & 24.489 & 9.821 & 66.061 & $5.928^{10}$ & 28 & 72.017 \\
\hline 2008 & 37.196 & 44.329 & 9.171 & 90.696 & $6.038^{11}$ & 53 & 96.787 \\
\hline 2009 & 44.463 & 28.160 & 5.764 & 78.387 & $3.240^{12}$ & 37 & 86.647 \\
\hline
\end{tabular}

Vir: ZRSZ

Porast števila osebnih delovnih dovoljenj je posledica sprememb ZZDT v letih 2005 in 2007. S spremembami ZZDT so osebno delovno dovoljenje lahko pridobili še:

- $\quad$ tujec z najmanj poklicno izobrazbo, ki je bil zadnji dve leti pred vložitvijo vloge neprekinjeno zaposlen pri istem delodajalcu,

10 Število zaposlitev v letu 2007.

11 Število zaposlitev v letu 2008.

12 Število zaposlitev v letu 2009. 


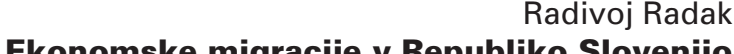

- delovni migrant, ki je bil zadnji dve leti pred vložitvijo vloge neprekinjeno zaposlen pri istem delodajalcu,

- tujec, ki je zadnji letnik šolanja končal $\vee$ Republiki Sloveniji in pridobil najmanj visokošolsko izobrazbo, če si $\vee$ roku enega leta od pridobljenega naziva najde delodajalca ali se samozaposli,

- tujec, ki je $\vee$ Sloveniji zaključil program raziskovalnega dela in si v roku enega leta najde delodajalca ali se samozaposli,

- ožji družinski član raziskovalca in

- oseba s subsidiarno zaščito.

Rast števila dovoljenj za zaposlitev, dovoljenj za delo in EU-prijav je bila posledica velike gospodarske rasti, $v$ letu 2009 pa se kaže izrazit padec števila teh dovoljenj zaradi svetovne gospodarske krize.

Tudi na ravni Evropske unije so si države članice prizadevale vzpostaviti boljši pravni red na področju ekonomskih imigracij iz t.i. tretjih držav.

Cilj vseh politik na področju notranjih zadev iz prvega stebra "vizumi, azil, priseljevanje in druge politike $v$ zvezi s prostim gibanjem oseb" (Naslov IV Pogodbe o ustanovitvi Evropske skupnosti) $\vee$ prihodnosti bo njihova medsebojna povezanost in sodelovanje, celovit pristop, vzpostavitev njihove zunanje dimenzije ter večji poudarek na solidarnosti, pravični delitvi odgovornosti vključno s finančnimi posledicami in na tesnejšem praktičnem sodelovanju med državami članicami. V okviru razvoja navedenih politik je Evropski svet 5. novembra 2004 $\checkmark$ petletnem strateškem Haaškem programu za krepitev svobode, varnosti in pravice $\vee$ EU 2004-2009 poudaril pomen celovitega upravljanja mednarodnih migracij. Glede migracij se Haaški program osredotoča predvsem na zakonito priseljevanje, boj proti nezakonitemu zaposlovanju, vključevanju zakonitih priseljencev, partnerstvo s tretjimi državami, vračanje nezakonitih priseljencev in ponovni sprejem, kontrolo meja in boj proti nezakonitemu priseljevanju.

Kot prvi resnejši poskus vzpostavljanja enotnejše migracijske politike na ravni Evropske skupnosti lahko štejemo predlog direktive o ekonomskem priseljevanju iz leta $2001^{\mathbf{1 3}}$, ki jo je Evropska komisija predlagala zaradi urejanja pogojev vstopa in bivanja vseh državljanov tretjih držav, ki opravljajo plačane dejavnosti in dejavnosti na področju samozaposlitev. Predlog je bil splošen okvir za vse tipe ekonomskih migrantov, vendar pa zaradi različnih pogledov in

13 Proposal for a Council Directive on the conditions of entry and residence of third-country nationals for the purpose of paid employment and self-employed economic activities, $\operatorname{COM}(2001) 386$ final. 


\section{Radivoj Radak}

\section{Ekonomske migracije v Republiko Slovenijo}

interesov držav članic ni dobil zadostne podpore $v$ Svetu, čeprav je formalna ureditev sprejema ekonomskih migrantov eden od temeljev vsake migracijske politike.

Trenutno pogoje vstopa in prebivanja državljanov tretjih držav urejajo naslednje direktive:

- Direktiva o pravici do združitve družine ${ }^{\mathbf{1 4}}$

- Direktiva o statusu državljanov tretjih držav, ki so rezidenti za daljši čas ${ }^{\mathbf{1 5}}$,

- Direktiva o pogojih za sprejem državljanov tretjih držav za namen študija, izmenjav učencev, neplačanega usposabljanja ali prostovoljnega dela ${ }^{{ }^{16}}$,

- Direktiva o posebnem postopku za dovolitev vstopa državljanom tretjih držav za namene znanstvenega raziskovanja ${ }^{17}$

- Direktiva o minimalnih standardih glede sankcij in ukrepov zoper delodajalce, ki zaposlujejo nezakonito prebivajoče državljane tretjih držav ${ }^{\mathbf{1 8}}$ in

- Direktiva o pogojih za vstop in prebivanje državljanov tretjih držav za namene visokokvalificirane zaposlitve ${ }^{\mathbf{1 9}}$.

$\checkmark$ obliki predloga, oziroma delovnega gradiva Komisije pa so še naslednje direktive:

- Splošna okvirna direktiva o pravicah priseljencev iz tretjih držav in enotnem dovoljenju za delo in prebivanje,

- Direktiva v zvezi s pogoji vstopa in prebivanja sezonskih delavcev,

- Direktiva $v$ zvezi s postopki urejanja vstopa ter bivanja premeščencev znotraj podjetja in

- Direktiva v zvezi s pogoji vstopa in prebivanja plačanih pripravnikov.

14 Direktiva Sveta 2003/86/ES o združitvi družine.

15 Direktiva Sveta 2003/109/ES o statusu državljanov tretjih držav, ki so rezidenti za daljši čas.

16 Direktiva Sveta 2004/114/ES o pogojih za sprejem državljanov tretjih držav za namen študija, izmenjav učencev, neplačanega usposabljanja ali prostovoljnega dela.

17 Direktiva Sveta 2005/71/ES o posebnem postopku za dovolitev vstopa državljanom tretjih držav za namene znanstvenega raziskovanja.

18 Direktiva 2009/52/ES Evropskega parlamenta in Sveta o minimalnih standardih glede sankcij in ukrepov zoper delodajalce, ki zaposlujejo nezakonito prebivajoče državljane tretjih držav.

19 Direktiva Sveta 2009/50/ES o pogojih za vstop in prebivanje državljanov tretjih držav za namene visokokvalificirane zaposlitve. 


\section{Ekonomske migracije v Republiko Slovenijo}

\section{Zaključek}

Zakon o zaposlovanju tujcev, od leta 2000 Zakon o zaposlovanju in delu tujcev, se je spreminjal in dopolnjeval glede na potrebe gospodarstva, oziroma stanje na trgu dela. Od urejanja statusa delavcev bivše skupne države in osnovnih razmerij med delodajalci in tujimi delavci (delovno dovoljenje na vlogo delodajalca), urejenih $\vee$ prvem Zakonu o zaposlovanju tujcev, je Zakon o zaposlovanju in delu tujcev uredil vse oblike dela in zaposlovanja tujcev, ki jih poznajo tudi druge države članice Evropske unije. S polnopravnim članstvom Slovenije $\vee$ Evropski uniji je Slovenija prevzela pravni red Evropske unije na področju prostega pretoka oseb in dodatno posodobila Zakon o zaposlovanju in delu tujcev. Slovenija, oziroma njeni predstavniki danes aktivno sodelujejo pri pripravi evropske zakonodaje na tem področju.

Novi izzivi za države članice Evropske unije se kažejo v dolgoročnem pomanjkanju delovne sile, kot posledice staranja aktivnega dela prebivalstva. Zato morata Slovenija in Evropska unija, ob upoštevanju demografskih gibanj in potreb trga dela, čim prej odgovoriti na vprašanje, kakšen bo trg dela $v$ prihodnosti. Prvi ukrep na tem področju je sprejem Direktive o visokokvalificiranih delavcih (t.i. EU Blue card), s katero so se države članice na ravni Evropske unije vključile $v$ boj z Združenimi državami Amerike, Kanado in Avstralijo za kadre iz t.i. tretjih držav. Še bolj pomemben ukrep za oblikovanje skupne migracijske politike držav EU pa je načrtovani sprejem predloga Direktive o enotnem postopku za izdajo enotnega dovoljenja ter o skupnem okvirju pravic za delavce iz tretjih držav, ki zakonito prebivajo $v$ državi članici.

Zaradi zgodovinskih, kulturnih in jezikovnih razlogov so slovenski delodajalci najbolj zadovoljni z delavci iz bivših republik skupne države, kar se kaže tudi na številu delovnih dovoljenj, izdanih državljanom teh držav. Zaradi navedenega in enostavnejšega ter učinkovitejšega načina upravljanja z delovnimi imigracijami, se Ministrstvo za delo, družino in socialne zadeve načrtno usmerja v sklepanje bilateralnih sporazumov o zaposlovanju z državami nekdanje Jugoslavije. Ena prvih tretjih držav, s katero se bodo že v februarju 2010 začeli pogovori o sklenitvi sporazuma o zaposlovanju, je Bosna in Hercegovina, iz katere prihaja največ tujih delavcev na slovenski trg dela. 


\section{Radivoj Radak \\ Ekonomske migracije v Republiko Slovenijo}

Radivoj Radak je univerzitetni diplomirani pravnik, ki že 15 let dela na Ministrstvu za delo, družino in socialne zadeve, ves čas na področju delovnih migracij. Pred tem je več kot 9 let delal kot pravnik v Iskri Polprevodniki, oziroma Iskri Semicon iz Trbovelj.

\section{Viri}

- (2003). Direktiva Sveta 2003/86/ES z dne 22. septembra 2003 o pravici do združitve družine. Uradni list EU, št. 155 z dne 3.10.2003.

- (2003). Direktiva Sveta 2003/109/ES z dne 25. novembra 2003 o statusu državljanov tretjih držav, ki so rezidenti za daljši čas. Uradni list EU, št. 16 z dne 23. 1. 2004.

- (2004). Direktiva Sveta 2004/114/ES z dne 13. decembra 2004 o pogojih za sprejem državljanov tretjih držav za namene študija, izmenjav učencev, neplačanega usposabljanja ali prostovoljnega dela. Uradni list EU, št. 375, 23. 12. 2004.

- (2004). Direktiva Evropskega parlamenta in Sveta 2004/38/ES z dne 29. aprila 2004 o pravici državljanov Unije in njihovih družinskih članov do prostega gibanja in prebivanja na ozemlju držav članic. Uradni list EU, št. 158 z dne 30.4.2004.

- (2005). Direktiva Sveta 2005/71/ES z dne 12. oktobra 2005 o posebnem postopku za dovolitev vstopa državljanov tretjih držav za namene znanstvenega raziskovanja. Uradni List EU, št. 289, 3. 11. 2005.

- (2009). Direktiva 2009/52/ES Evropskega parlamenta in Sveta z dne 18. junija 2009 o minimalnih standardih glede sankcij in ukrepov zoper delodajalce, ki zaposlujejo nezakonito prebivajoče državljane tretjih držav. Uradni list EU, št. 168, 30.6.2009.

- (2009). Direktiva Evropskega parlamenta in Sveta 2009/50/ES z dne 25. maja 2009 o pogojih za vstop in prebivanje državljanov tretjih držav zaradi zaposlitve za visokokvalificirane delavce. Uradni list EU, št. 155 z dne 18.6.2009.

- (2001). Proposal for a Council Directive on the conditions of entry and residence of thirdcountry nationals for the purpose of paid employment and self-employed economic activities. $\operatorname{COM}(2001) 386$ final.

- (2008). Pravilnik o delovnih dovoljenjih, prijavi in odjavi dela ter nadzoru nad zaposlovanjem in delom tujcev. Uradni list RS, št. 37/08.

- $\quad$ (1999). Resolucija o imigracijski politiki Republike Slovenije. Uradni list RS, št. 40/99.

- (1968). Uredba Sveta št. 1612/68 (EGS) z dne 15. oktobra 1968 o prostem gibanju delavcev v Skupnosti. Uradni list EU, št. 257 z dne 19.10.1968.

- (1971). Uredba Sveta (EGS) št. 1408/71 z dne 14. junija 1971 o uporabi sistemov socialne varnosti za zaposlene osebe in njihove družinske člane, ki se gibljejo v Skupnosti. Uradni list EU, št. 149 z dne 5.7.1971. (2009). 
Radivoj Radak

Ekonomske migracije v Republiko Slovenijo

- (2009). Uredba o omejitvah in prepovedih zaposlovanja in dela tujcev. Uradni list RS, št. 44/09.

- (1992). Zakon o zaposlovanju tujcev. Uradni list RS, št. 33/92.

- (2000). Zakon o zaposlovanju in delu tujcev. Uradni list RS, št. 66/00 in 101/05 in 52/07. 
Radivoj Radak

Ekonomske migracije v Republiko Slovenijo

SUMMARY

\section{LABOUR MIGRATION TO THE REPUBLIC OF SLOVENIA}

After the independence the Republic of Slovenia has found itself in a new position concerning the system of international migration flows and regulation of labour migration. The conditions for work and employment of third country citizens or stateless persons were defined by the Employment of Aliens Act (Official Gazette of RS, No. 33/92), which was among the first laws adopted after independence. Only with the Resolution on the Migration Policy of the Republic of Slovenia (Official Gazette of RS, No. 40/99) a few years later the first basis of the immigration policy of the Republic of Slovenia has been set out.

In the context of the legislative solutions only those forms of work have been covered in detail, which were related to the employment relationship (employment with employers and contract work, as stipulated by the Employment Relationships Act) taking into account the labour market conditions. Other forms of work arising from the right of people to perform activities with personal work (craft and craft related activities) were regulated in other laws (Article 10). The Employment of Aliens Act allowed this only when an alien was given permission by other competent authority. Even the work of other foreign natural and legal persons, who have under different conditions obtained income from work in the Republic of Slovenia, the Employment of Aliens Act has not regulated in detail. Most often, this was in the interest of foreign companies, which provided services by using posted workers. For providing services with the posted workers, the foreign company had to obtain a business visa for its posted workers (Article 11). These cases were stipulated in Article 8 of the Aliens Act, but they were not stipulated when the conditions for obtaining a business visa has been fulfilled. Aliens Act referred to the rules which governed foreign investment and foreign trade business or the exercise of professional work specified in the contract on business-technical cooperation or cooperative long-term production or technology transfer.

On the basis of resolution and in accordance with the National Program of the Republic of Slovenia for the adoption of the Acquis by the end of 2002 the Republic of Slovenia adopted a new Employment and work of Aliens Act (Official Gazette of RS, No. 66/00), which introduced a 
quota system as the main instrument for regulation of influx of foreign labour force (the threshold was $5 \%$ of the working population).

The Republic of Slovenia became a member of the European Union on 1st May 2004 and began to exercise the principle of free movement of workers, which has been since the Treaty of Rome in 1957, one of the cornerstones of a free market: free movement of goods, services, capital and persons.

With the new systemic law main resolution objectives in the legislative field were codified, namely the systemic link of the Employment and work of Aliens Act with the Aliens Act, regulation of access to the labour market depending on the type or purpose of the work and duration of activities (with different types of work permits, a personal work permit, employment permit, work permit, registration of work), selectivity in limiting access to employment and work depending on the nature of work and labour market conditions, priority treatment of already settled immigrants before the new aliens seeking employment and work, combining the right of employment and work with the right of residence (residents, aliens who were a long term residents, refugees, descendants of Slovenian citizens, family members) and the possibility of managing economic immigration with restrictive statutory instruments (quotas, prohibitions and restrictions, which may be adopted by The Government of the Republic of Slovenia under the conditions and manner specified by the Employment and work of Aliens Act).

Employment and work of Aliens Act imposed a quota system as the main instrument for regulation of the influx of alien labour force, with the threshold $5 \%$ of the working population. The quota restriction was intended for categories of aliens who came yearly in the Republic of Slovenia for the purpose of employment or the provision of other temporary forms of work on different contractual bases. In addition to the quota law also had other instruments to regulate the labour market conditions, which were the responsibility of the Government of the Republic of Slovenia. The government could adopt them if there was a too large influx of foreign labour force which in various forms can affect the deterioration of employment on the domestic labour market.

By signing the Treaty of Accession of 10 new Member States to the European Union, in Athens on 16 of April 2003, negotiations with the 15 "old" Member States on the conditions of accession were completed. The transition period applied only to the free movement of workers, while for 
Radivoj Radak

Ekonomske migracije v Republiko Slovenijo

the recognition of professional qualifications, the coordination of social security and civil rights EU Acquis applied from the first day of Slovenia's accession to EU. In accordance with the Treaty of Accession of 16 April 2003 old Member State could not introduce new restrictive measures in their national legislation against the citizens of new Member States nor could the new Member States introduce them against citizens of the current Member States.

In the eight years of implementation of the Employment and work of Aliens Act some ambiguities and shortcomings had been revealed, which allowed the misuse of the law, therefore in the years 2005 and 2007 amendments to Act were adopted.

The global economic crisis and the number of unemployed persons in Slovenia grew since September 2008 when there were only 59,303 unemployed persons, at the end of 2008 66,239, at the end of May 2009 84,519 , and at the end of 200996,672 unemployed persons. Therefore the Government adopted a Regulation on restrictions and prohibitions of employment and work of Aliens on 11 June 2009. The regulation was issued on the basis of the seventh paragraph Article 5 of Employment and work of Aliens Act, which stipulates, that the Government can in addition to the overall quota, also set restrictions and prohibitions on the employment of or work by aliens by region, area of activity, company and occupation, as well as restrict or prohibit the inflow of new alien workers, in its entirety or from specific regions if there are well-founded reasons that this is in the public interest or the general commercial interest. Regulation came into force on 13 June 2009.

On 5 November 2004, in the context of development common policies, the European Council emphasized the importance of integrated management of international migration by adopting The Hague Five-year Strategic Program for Strengthening Freedom, Security and Justice in the EU 2004-2009. New challenges for European Union Member States are reflected in long-term labour shortages, as a result of active aging of the population. Taking into account demographic trends and labour market needs, Slovenia and the European Union will have to define the future labour market as soon as possible. The first action in this area has been adoption of the Directive on highly-skilled workers (so-called EU Blue Card directive) with which the Member States at European Union level can step into "the fight" with the United States, Canada and Australia for highly skilled workers from third countries. 